\title{
Fluoxetine Can Inhibit SARS-CoV-2 In Vitro
}

\author{
Arthur Dechaumes ${ }^{1}$, Magloire Pandoua Nekoua ${ }^{1}$, Sandrine Belouzard ${ }^{2}$, Famara Sane ${ }^{1}$, Ilka Engelmann ${ }^{1}$, \\ Jean Dubuisson ${ }^{2}$ (D), Enagnon Kazali Alidjinou ${ }^{1}$ and Didier Hober ${ }^{1, *}$
}

1 Laboratoire de Virologie ULR3610, Univ Lille, CHU Lille, 59000 Lille, France; a.dechaumes@gmail.com (A.D.); magloire.nekoua@gmail.com (M.P.N.); famara.sane@chru-lille.fr (F.S.); ilka.engelmann@chru-lille.fr (I.E.); enagnonkazali.alidjinou@chru-lille.fr (E.K.A.)

2 Virologie Moléculaire et Cellulaire des Coronavirus, Centre D'infection et D'immunité de Lille, Institut Pasteur de Lille, Université de Lille, CNRS, Inserm, CHRU, 59000 Lille, France; sandrine.belouzard@ibl.cnrs.fr (S.B.); jean.dubuisson@ibl.cnrs.fr (J.D.)

* Correspondence: didier.hober@chru-lille.fr; Tel.: +33-(0)3-2044-6688

check for updates

Citation: Dechaumes, A.; Nekoua, M.P.; Belouzard, S.; Sane, F.; Engelmann, I.; Dubuisson, J.; Alidjinou, E.K.; Hober, D. Fluoxetine Can Inhibit SARS-CoV-2 In Vitro. Microorganisms 2021, 9, 339. https://doi.org/10.3390/ microorganisms 9020339

Academic Editor: Paolo Calistri

Received: 8 January 2021

Accepted: 4 February 2021

Published: 9 February 2021

Publisher's Note: MDPI stays neutral with regard to jurisdictional claims in published maps and institutional affiliations.

Copyright: (c) 2021 by the authors. Licensee MDPI, Basel, Switzerland. This article is an open access article distributed under the terms and conditions of the Creative Commons Attribution (CC BY) license (https:/ / creativecommons.org/licenses/by/ $4.0 /)$.

\begin{abstract}
An outbreak of severe acute respiratory syndrome coronavirus 2 (SARS-CoV-2) resulted in the coronavirus disease pandemic, drastically affecting global health and economy. Though the understanding of the disease has improved, fighting the virus remains challenging. One of the strategies is repurposing existing drugs as inhibitors of SARS-CoV-2. Fluoxetine (FLX), a selective serotonin reuptake inhibitor, reportedly inhibits the replication of RNA viruses, especially Coxsackieviruses $\mathrm{B}(\mathrm{CVB})$, such as CV-B4 in vitro and in vivo. Therefore, in this study, we investigated the in vitro antiviral activity of FLX against SARS-CoV-2 in a model of acute infection. When $10 \mu \mathrm{M}$ of FLX was added to SARS-CoV-2-infected Vero E6 cells, the virus-induced cytopathic effect was not observed. In this model, the level of infectious particles in the supernatant was lower than that in controls. The level was below the limit of detection of the assay up to day 3 post-infection when FLX was administered before viral inoculation or simultaneously followed by daily inoculation. In conclusion, FLX can inhibit SARS-CoV-2 in vitro. Further studies are needed to investigate the potential value of FLX to combat SARS-CoV-2 infections, treat SARS-CoV-2-induced diseases, and explain the antiviral mechanism of this molecule to pave way for novel treatment strategies.
\end{abstract}

Keywords: SARS-CoV-2; coronavirus; fluoxetine; in vitro

\section{Introduction}

The city of Wuhan, China, first faced the outbreak caused by severe acute respiratory syndrome coronavirus 2 (SARS-CoV-2) in December 2019. The World Health Organization declared the epidemic to be a public health emergency of international concern, and the outbreak quickly grew into a global pandemic. Most common symptoms of COVID-19 include fever, cough, dyspnea, and myalgia. The most common complication is acute respiratory distress syndrome, affecting $3.4 \%$ of infected patients and $15.6-17.0 \%$ of severe patients [1]. In January 2021, a cumulative total of nearly 97 million confirmed cases and 2 million deaths have been reported since the start of the outbreak (WHO 2021).

The survival of SARS-CoV-2 in the environment (air, surfaces, and water) depends on the size of particulate matter and aerosols, humidity, and temperature [2]. Since environmental pollutants have been shown to alter the immune system, several studies showed that air pollution significantly increases the risk of acute respiratory infection and the severity of COVID-19 [3-6]. It was also reported that emission of immunomodulating bioactive volatile organic compounds (VOCs) by evergreen forested areas has a protective role on population against SARS-CoV-2 which suggests the importance of nature conservation in reducing the harmful effects of the global pandemic [7].

SARS-CoV-2 is a positive sense RNA virus with a relatively large genome of around $30 \mathrm{~kb}$ belonging to the Coronaviridae family. Its genome encompasses five major open reading frames, namely replicase polyproteins, nucleocapsid proteins, spike proteins, 
envelope proteins, and membrane glycoproteins [8], with a $5^{\prime}$-methylguanosine cap at the beginning and a $3^{\prime}$-poly-A tail at the end encompassing 6 to 10 genes. The order of the genes is usually highly conserved; the first gene is replication and transcription-related and the rest, structural. The replication and transcription-related gene is transcribed and then translated into two large non-structural polyproteins [9]. The spike protein, envelope protein, membrane protein, nucleocapsid protein, 3CL protease, papain-like protease, RNA polymerase, and helicase protein have been suggested as viable antiviral drug targets [10].

Though trials on SARS-CoV-2 genome-based vaccines and therapeutic antibodies are being tested, they represent a long-term solution and short-term solutions such as standard treatments against SARS-CoV-2 are lacking; the wide range of antivirals currently being marketed show no significant activity. Therefore, repurposing existing drugs and antiviral agents is pragmatic and an efficient short-term approach; however, it remains crucial to determine new potential antiviral targets. Several antivirals (remdesivir, favipiravir) and antimalarials (chloroquine, hydroxychloroquine) have emerged as potential therapies [11-13]. Despite the candidate drugs such as remdesivir and hydroxychloroquine target different viral infection response pathways or directly interfere with the SARS-CoV2 replication cycle in vitro, none of them revealed any effect on mortality, mechanical ventilation, and length of hospital stay of patients with COVID-19 [14,15].

Analogous to coronaviruses, Picornaviridae family members such as coxsackieviruses $\mathrm{B}$ (Enterovirus genus) are also positive sense RNA viruses but with smaller genome size (around $7.5 \mathrm{~kb}$ ) [16]. Multiple direct-acting inhibitors, such as capsid binders or inhibitors of viral enzymes required for genome replication, have been clinically evaluated, but some of them failed because of limited efficacy or toxicity issues [17]. Hence, host-targeting inhibitors with potential broad-spectrum activity should be a useful strategy to fight enterovirus and coronavirus infections.

Recently, fluoxetine (FLX), a selective serotonin reuptake inhibitor, has been reported as an inhibitor of several viruses, such as dengue [18], hepatitis C [19], SARS-CoV-2 [20,21], and enterovirus in vitro [22].

This drug was formerly used to treat depression and other mental disorders. We and others previously demonstrated a significant antiviral activity against coxsackieviruses B (CVB) 1-4 in vivo and in vitro [23-26]. FLX can inhibit the replication of CVB4 E2 in a cell line (Panc-1) model of human pancreatic cells [25]. Owing to these inhibitory characteristics of FLX in vitro and in vivo, we investigated the antiviral activity of FLX against SARS-CoV-2 in Vero E6 cells.

\section{Materials and Methods}

SARS-CoV-2 was isolated from a positive respiratory specimen tested using the polymerase chain reaction (PCR) test at the Department of Virology, CHU Lille. VERO-81 cells were transduced with a retroviral vector expressing TMPRSS2 to enhance virus entry [27]. Cells were seeded in T125 flasks and inoculated with $500 \mu \mathrm{L}$ of the oropharyngeal specimen. Cytopathic effects (CPE) were observed $48 \mathrm{~h}$ later, and supernatants were collected $72 \mathrm{~h}$ after inoculation. TMPRSS2-transduced VERO-81 cells were subjected to $100 \mu \mathrm{L}$ of these supernatants. Then, these supernatants were collected following the appearance of CPEs. The isolate was amplified in TMPRSS2-transduced VERO-81 cells and passaged twice to produce the viral stock. Viral stocks were stored in liquid nitrogen $\left(-196{ }^{\circ} \mathrm{C}\right)$ with no stabilizer. After thawing, they were inoculated in the medium containing Vero E6 cells. For virus propagation, SARS-CoV-2 was cultured in Vero E6 cells (ATCC) maintained in DMEM (Gibco) supplemented with 10\% heat-inactivated fetal bovine serum (Gibco), $100 \mathrm{U} / \mathrm{mL}$ penicillin, and $100 \mu \mathrm{g} / \mathrm{mL}$ streptomycin (Gibco) in T75 flasks and incubated at $37{ }^{\circ} \mathrm{C} / 5 \% \mathrm{CO}_{2}$. The specificity of the SARS-CoV-2 isolate was assessed using real-time reverse transcription (qRT)-PCR. Viral RNA extraction was performed with the MagNA Pure Compact Nucleic Acid Isolation Kit using the MagNA Pure Compact Instrument (Roche Life Science, Meylan, France). SARS-CoV-2 detection was performed with an inhouse real-time duplex RT-PCR assay, targeting two regions in the RdRp gene (IP2 and 
IP4), designed by the Pasteur Institute of Paris [28]. GAPDH was used as the housekeeping gene to monitor specimen quality, extraction, and PCR inhibition.

The CV-B4 E2 strain was provided by Ji-Won Yoon (Julia McFarlane Diabetes Research Centre, Calgary, AB, Canada). This strain was propagated in HEp-2 cells (ATCC) that were cultivated in complete MEM medium (Gibco) enriched with $10 \%$ heat-inactivated fetal bovine serum. Culture supernatants were recovered 5 days post-infection, centrifuged at $800 \times g$ for $5 \mathrm{~min}$ at $20^{\circ} \mathrm{C}$, and filtered through $0.22-\mu \mathrm{m}$ filter membranes. Aliquots were stored at $-80{ }^{\circ} \mathrm{C}$. The virus titers were determined as the tissue culture $50 \%$ infectious dose $\mathrm{TCID}_{50} / \mathrm{mL}$ using the Spearman-Karber method.

Fluoxetine hydrochloride (Sigma-Aldrich, Saint-Quentin Fallavier, France) was dissolved in dimethyl sulfoxide (DMSO). To evaluate the antiviral activity of FLX, Vero E6 cells were seeded in 24-well plates at $5 \times 10^{4}$ cells per well and inoculated with the virus at a MOI of 0.01 mixed with various dilutions of FLX or DMSO. The plates were incubated at $37^{\circ} \mathrm{C}$, and cell cultures were observed for CPE daily.

CPE was observed under an inverted microscope (Magnification $\times 100$ ). Orangu ${ }^{\mathrm{TM}}$ (Cell Guidance Systems, Cambridge, UK) was used to measure cell viability according to the manufacturer's instructions. Viral titers determined in supernatants of infected cells were assessed using the endpoint dilution assay, and the Spearman-Karber statistical method was used to determine the tissue culture $50 \%$ infectious dose $\left(\mathrm{TCID}_{50} / \mathrm{mL}\right.$ ).

\section{Results}

A SARS-CoV-2 isolate obtained from a respiratory sample was able to infect a Vero E6 cell monolayer in less than 3 days with a high titer at $10^{7.5} \mathrm{TCID}_{50} / \mathrm{mL}$. We studied this in vitro model of SARS-CoV-2 infection to evaluate the antiviral activity of FLX against the virus.

FLX concentrations beyond $50 \mu \mathrm{M}$ reduced the viability of Vero E6 (Figure 1a). Therefore, concentrations ranging from 0 to $10 \mu \mathrm{M}$ were used to evaluate the antiviral activity of FLX in these cells. As it was reported that FLX can inhibit the infection of HEp-2 cells with CV-B4, we decided to first study whether FLX can inhibit the infection of Vero E6 cells with CV-B4; $10 \mu \mathrm{M}$ of FLX was added to Vero E6 cells cultures along with CV-B4 E2, the cells were incubated for $2 \mathrm{~h}$, and then cultures were washed before continuing with incubation. The infection was inhibited as evidenced with the viability index of cells, which was $86 \pm 4 \%$ and $98 \pm 6 \% 48$ h post-inoculation, when treated with 5 and $10 \mu \mathrm{M}$ of FLX, respectively, whereas the value was below $20 \%$ when the infected cells were not treated. The infectious titer of supernatants was below the limit of detection $48 \mathrm{~h}$ after adding FLX to cell cultures, whereas it was $(2.2 \pm 1.6) \times 10^{6} \mathrm{TCID}_{50} / \mathrm{mL}$ in infected cells not treated with FLX (Figure 1b).

These data showing the antiviral effect of FLX in Vero E6 prompted us to study the effect of FLX in Vero E6 infected with SARS-CoV-2. No CPE was observed (data not shown), and the level of infectious particles in supernatants was below the limit of detection $24 \mathrm{~h}$ post-infection. However, $48 \mathrm{~h}$ post-infection, this level was $10^{3.5} \mathrm{TCID} 50 / \mathrm{mL}$, as high as $10^{5}$ $\mathrm{TCID}_{50} / \mathrm{mL}$ the day after, and $2.3 \times 10^{6} \pm 1.8 \times 10^{6} \mathrm{TCID}_{50} / \mathrm{mL} 5$ days post-infection. In comparison, the level of infectious particles in supernatants of untreated infected cultures was already over $10^{5} \mathrm{TCID}_{50} / \mathrm{mL} 24 \mathrm{~h}$ post-infection and reached $2.3 \times 10^{6} 72 \mathrm{~h}$ postinfection (Figure 1c).

In the experiments that followed, FLX $(1,5$, or $10 \mu \mathrm{M})$ was added to Vero E6 cells cultures along with SARS-CoV-2, the cells were incubated for $2 \mathrm{~h}$, the cells were washed, and the same concentration of FLX $(1,5$, or $10 \mu \mathrm{M}$ accordingly) was added before continuing with incubation.

When less than $10 \mu \mathrm{M}$ of FLX was added to the cell cultures along with SARS-CoV-2, the infection was not inhibited. Indeed, $48 \mathrm{~h}$ post-infection, the viability indices of cells were $32 \pm 6.5 \%$ and $20 \pm 2 \%$ and infectious titers of supernatants were $2.4 \pm 1.2 \times 10^{6}$ $\mathrm{TCID}_{50} / \mathrm{mL}$ and $5.4 \pm 3.9 \times 10^{6} \mathrm{TCID}_{50} / \mathrm{mL}$ when infected cells were treated with 1 and $5 \mu \mathrm{M}$ of FLX, respectively. The same pattern of values was observed in untreated infected 
cells (Figure 1c). In contrast, in SARS-CoV-2-infected Vero E6 treated with $10 \mu \mathrm{M}$ of FLX, the virus-induced cytopathic effect was inhibited. Indeed, $48 \mathrm{~h}$ post-infection, the cell viability index was higher in FLX-treated cells than in controls ( $83 \pm 4 \%$ vs. $23 \pm 7 \% ; p=0.01)$. Moreover, the infectious titers of supernatants were $2.1 \pm 1.6 \times 10^{2} \mathrm{TCID}_{50} / \mathrm{mL}$. In some experiments, the viral titer was below the limit of detection of the assay (Figure 1d).

(a)

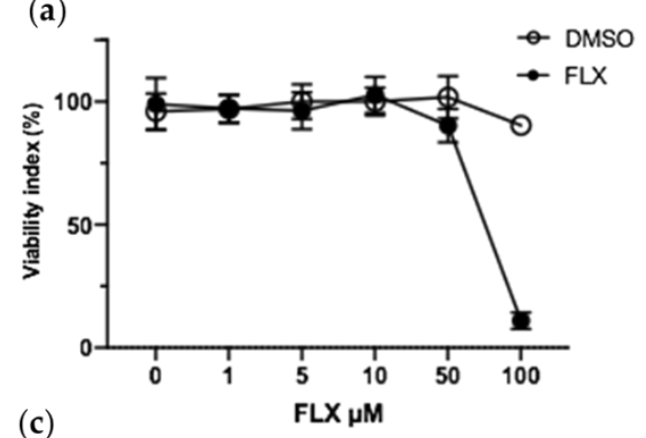

(c)

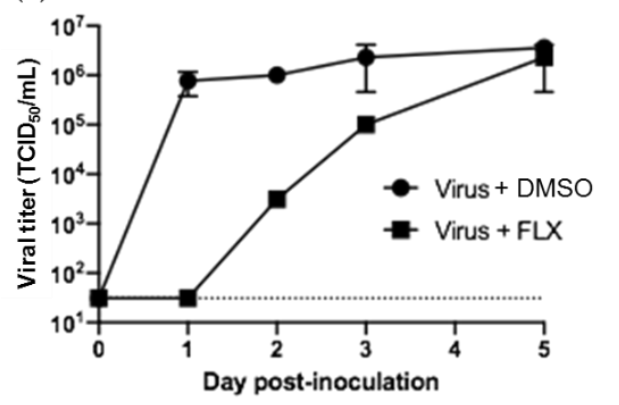

(b)
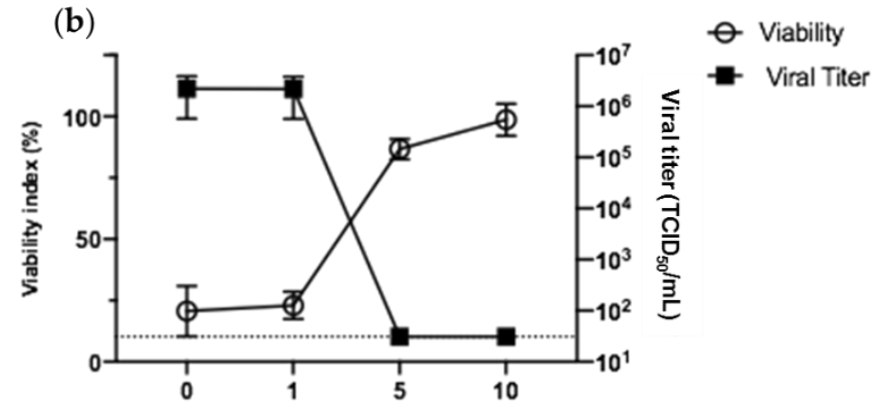

(d)

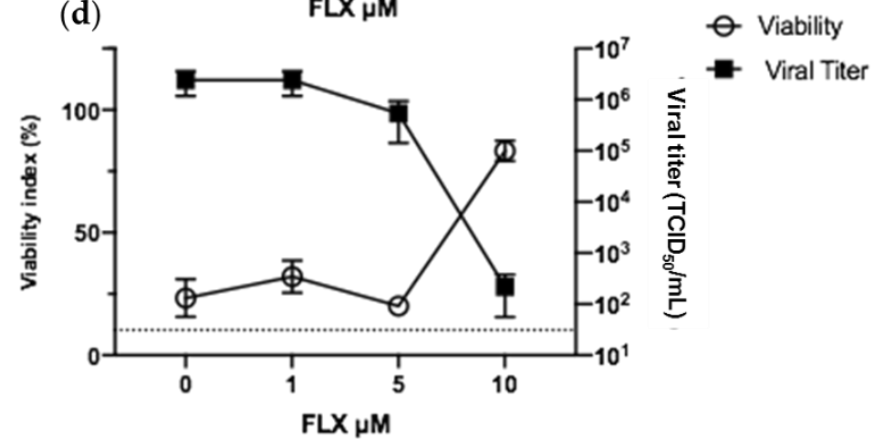

Figure 1. Fluoxetine (FLX) can inhibit the replication of severe acute respiratory syndrome coronavirus 2 (SARS-CoV-2) and CV-B4 E2 in Vero E6 cells. Vero E6 cells were seeded in 24-well plates at $10^{5}$ cells per well. (a) DMSO or various concentrations of FLX dissolved in DMSO were added to cell cultures to determine the cytotoxic concentrations. Cell viability was assessed using the Orangu assay after $72 \mathrm{~h}$. Optical density values are normalized using the viability value of uninfected cells (mock $=100 \%$ ). $(\mathbf{b})$ Vero E6 cells were inoculated with CV-B4 E2 at MOI 0.01 and various concentrations of FLX dissolved in DMSO were added to cell cultures at non-cytotoxic concentrations; the cells were washed $2 \mathrm{~h}$ postinoculation (DMSO conditions not shown). (c) Cell cultures were inoculated with SARS-CoV-2 at MOI 0.01 and $10 \mu \mathrm{M}$ of FLX; cells were washed $2 \mathrm{~h}$ post-inoculation. (d) Vero E6 cells were inoculated with SARS-CoV-2 at MOI 0.01 and various concentrations of FLX dissolved in DMSO at non-cytotoxic concentrations. The cells were washed $2 \mathrm{~h}$ post-inoculation, and either FLX was added at the same concentration or DMSO (DMSO conditions not shown). Day 2 post-infection, cell viability was expressed as \% compared with uninfected FLX-treated cells and levels of infectious particles were determined using the endpoint dilution assay. The Spearman-Karber method was used to determine the tissue culture $50 \%$ infectious dose $\left(\mathrm{TCID}_{50} / \mathrm{mL}\right)$. The results are expressed as the mean $\pm \mathrm{SD}$ of three independent experiments.

In these experiments, it was observed that $10 \mu \mathrm{M}$ of FLX could inhibit the infection of Vero E6 cells with SARS-CoV-2 when the molecule was added to the culture along with the virus and re-added after washings. Next, it was investigated whether an antiviral effect of FLX can be obtained when the molecule is added to cultures before or after the infection with SARS-CoV-2. To this end, Vero E6 cells were either inoculated with SARSCoV-2 or with the virus and $10 \mu \mathrm{M}$ of FLX or were treated with $10 \mu \mathrm{M}$ of FLX for $2 \mathrm{~h}$ before or after inoculating the virus. In all experiments, cell cultures were washed with complete medium three times to eliminate any residual virus particle. Then, $10 \mu \mathrm{M}$ of FLX was added or re-added according to the case for each condition except in controls. The level of infectious particles in supernatants was measured on days 1,2,3, and 5 postinfection. The level of infectious particles in supernatants of untreated cell cultures reached $3.16 \times 10^{6} \mathrm{TCID}_{50} / \mathrm{mL}$ as soon as $24 \mathrm{~h}$ post-infection. When the cells were inoculated with the virus along with FLX, the viral titer of supernatants of cell cultures was under the limit of detection $24 \mathrm{~h}$ post-infection, $1.42 \pm 1.50 \times 10^{2} \mathrm{TCID}_{50} / \mathrm{mL} 48 \mathrm{~h}$ post-infection, and 
$3.16 \times 10^{6} \mathrm{TCID}_{50} / \mathrm{mL} 5$ days post-infection. When the cells were infected and then treated with FLX $2 \mathrm{~h}$ post-infection, the levels of infectious particles in supernatants of cultures increased progressively and reached $1.3 \pm 1.9 \times 10^{6} \mathrm{TCID}_{50} / \mathrm{mL} 3$ days post-infection. When the cells were treated with FLX before the inoculation of SARS-CoV-2, the level of infectious particles in the supernatant of culture remained under the limit of detection up to 3 days post-infection and then reached $3.16 \times 10^{6} \mathrm{TCID}_{50} / \mathrm{mL}$ on day 5 post-infection (Figure 2).

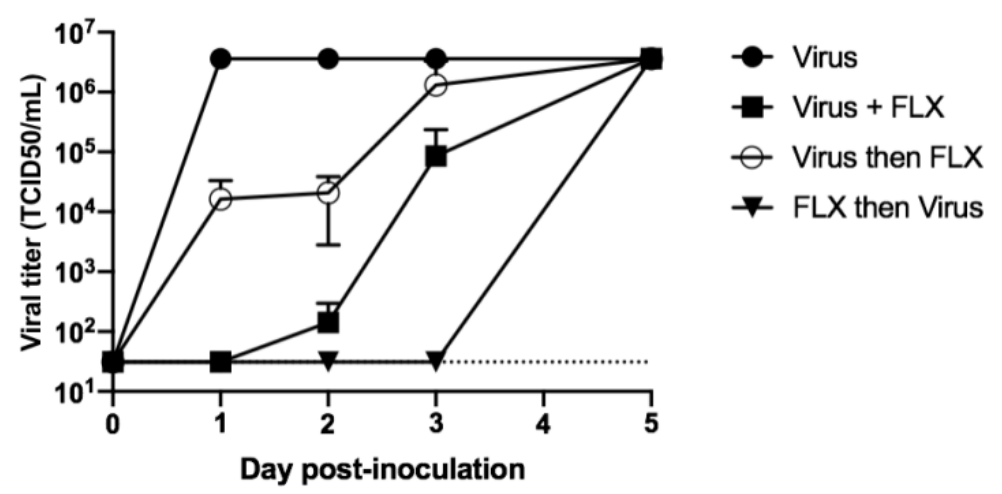

Figure 2. Levels of infectious particles in cell cultures treated with fluoxetine (FLX) before, during, or after inoculation of SARS-CoV-2. Vero E6 cells were seeded in 24 -well plates at $10^{5}$ cells per well. The cells were inoculated with SARS-CoV-2 (black circles), SARS-CoV-2 + $10 \mu \mathrm{M}$ of FLX (black squares), or SARS-CoV-2 incubated for $2 \mathrm{~h}$ and then treated with $10 \mu \mathrm{M}$ of FLX (white circles), or the cells were incubated for $2 \mathrm{~h}$ in presence of $10 \mu \mathrm{M}$ of FLX, followed by inoculation with SARS-CoV-2 and incubation for $2 \mathrm{~h}$ (black triangles). For each condition, the MOI was 0.01 and the cells were washed three times with complete medium after incubation and then treated again with $10 \mu \mathrm{M}$ of FLX, followed by re-incubation. Levels of infectious particles in supernatants were determined using the endpoint dilution assay at days 1, 2, 3, 5 post-infection. The Spearman-Karber method was used to determine the tissue culture $50 \%$ infectious dose $\left(\mathrm{TCID}_{50} / \mathrm{mL}\right)$. The results are presented as the mean $\pm \mathrm{SD}$ of three independent experiments.

Thus, the infection of Vero E6 cells can be inhibited when FLX is added to the cells before the inoculation of the virus and can be inhibited but at a lower extent and an extremely lower extent when FLX is added during and after the inoculation of the cells, respectively.

To investigate further the effect of FLX on the infection of Vero E6 cells with SARS-CoV2, cell cultures inoculated with FLX along with the virus were treated with $10 \mu \mathrm{M}$ of FLX or DMSO on days 1, 2, 3, 4, 5, and 7 post-infection. While $100 \%$ CPE was observed in untreated infected cell cultures, no CPE was observed up to day 3 post-infection in FLX-treated cell cultures (Figure $3 \mathrm{a}-\mathrm{c}$ ). The effect of FLX on infected cells was evaluated using the Orangu viability assay and through the level of infectious particles in culture supernatants collected from day 1 through day 9 post-infection. The cellular viability of FLX-treated infected cells was around $100 \%$ on day 3 post-infection and $85 \%$ on day 5 post-infection, then the values were $44 \pm 7 \%$ and $20 \pm 2 \%$ on days 7 and 9 post-infection (Figure $3 \mathrm{~d}$ ), respectively. The viability of infected cells was $70 \pm 7 \%$ on day 1 and $13 \pm 1.5 \%$ as soon as day 2 post-infection (Figure 3d). The level of infectious particles in supernatants of FLX-treated cell cultures remained under the limit of detection until day 3 post-infection and was $2.17 \pm 1.6 \times 10^{2} \mathrm{TCID}_{50} / \mathrm{mL}$ on day 5 post-infection and $5.4 \pm 3.9 \times 10^{4} \mathrm{TCID}_{50} / \mathrm{mL}$ on day 9 post-infection. In contrast, in untreated infected cells, the level of infectious particles reached $3.6 \times 10^{6} \mathrm{TCID}_{50} / \mathrm{mL}$ as soon as day 2 post-infection (Figure $3 \mathrm{~d}$ ). 

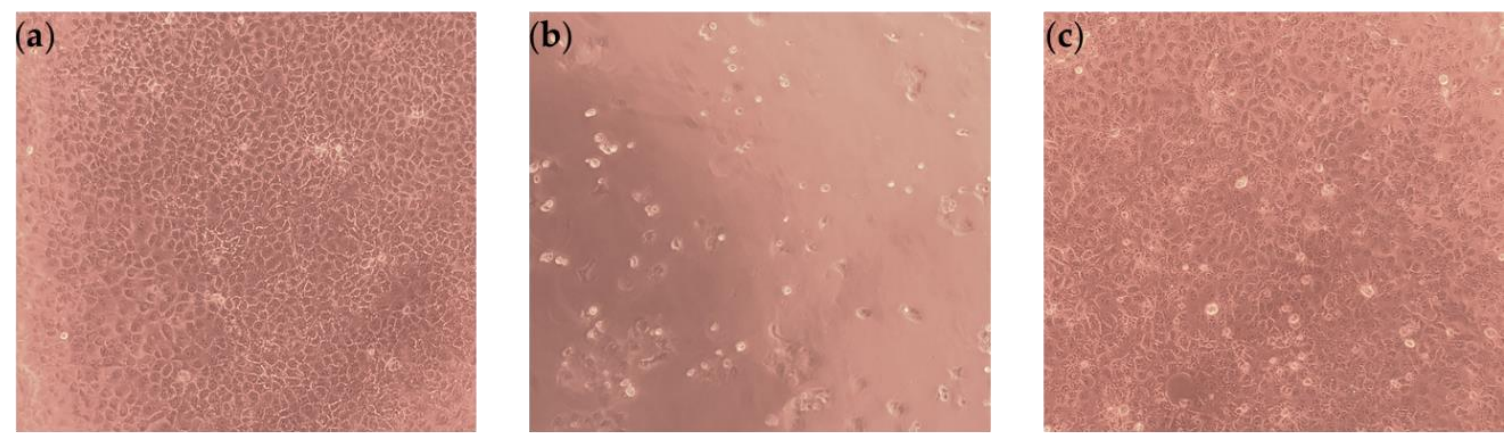

(d)

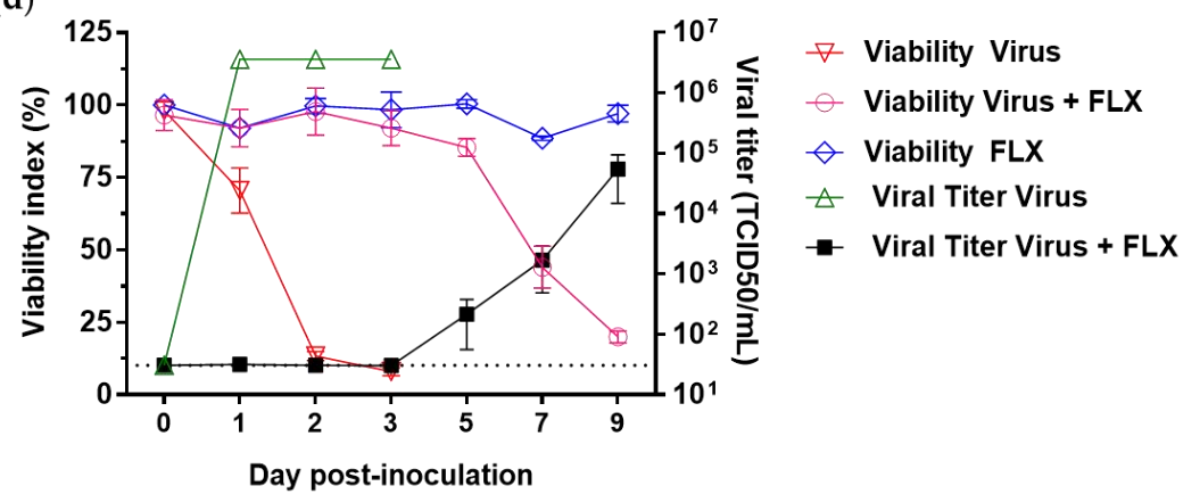

Figure 3. Levels of infectious particles in supernatants of SARS-CoV-2-infected Vero E6 cells treated daily with Fluoxetine (FLX). Cytopathic effects due to SARS-CoV-2 (MOI 0.01) in Vero E6 cells: (a) uninfected Vero E6 cells, (b) SARS-CoV-2infected Vero E6 cells, (c) SARS-CoV-2-infected Vero E6 cells treated with $10 \mu \mathrm{M}$ of FLX. The cells were observed under an inverted microscope (magnification $\times 100$ ) after $72 \mathrm{~h}$ of incubation. (d) Vero E6 cells were inoculated with SARS-CoV-2 (MOI 0.01 ) and treated with $10 \mu \mathrm{M}$ of FLX. After incubation for $2 \mathrm{~h}$, the cells were washed three times with complete medium and then $10 \mu \mathrm{M}$ of FLX was added. Cells were treated daily from day 1 to day 7 post-inoculation with $10 \mu \mathrm{M}$ of FLX. Cell viability was evaluated using the Orangu assay (inverted gray triangles, white circles, dark gray diamonds) and levels of infectious particles in the supernatants were determined using the endpoint dilution assay (gray triangles and black squares) from day 1 through day 9 post-infection. The Spearman-Karber method was used to determine the tissue culture $50 \%$ infectious dose $\left(\mathrm{TCID}_{50} / \mathrm{mL}\right)$. The results are presented as the mean $\pm \mathrm{SD}$ of three independent experiments.

\section{Discussion}

We previously demonstrated that FLX inhibits CV-B4 in vitro and in vivo $[25,26]$. Hence, we decided to test the inhibitory effect of FLX on SARS-CoV-2 cultured in Vero E6 cells. The methodology of the current study is different in many respects from those of other teams. Indeed, FLX was administered after or before SARS-CoV-2 inoculation to cells, or simultaneously, followed by daily inoculation to evaluate the potential value of this molecule in the prophylaxis and/or the treatment of the infection. The infection of Vero E6 cells was evaluated through the CPE in Vero E6 cells line cultures, viability index compared with that of mock-infected cells, and level of infectious particles in supernatants of these cultures. The activity of FLX against SARS-CoV-2 was evaluated considering the inhibition of virus-induced $\mathrm{CPE}$, cellular viability compared with that of mock-infected cells, and reduction of titers of infectious particles in supernatants.

It was determined that FLX was not cytotoxic in our system at concentrations lower than $50 \mu \mathrm{M}$ and that FLX could inhibit the infection of Vero E6 cells with CV-B4. Interestingly, we observed that $10 \mu \mathrm{M}$ of FLX inhibited the infection of these cells with SARS-CoV-2.

FLX can have a short half-life depending on the species [29], which can explain why administration of only one dose of the molecule to cultures resulted in the shifting of the onset of CPE and high levels of infectious particles in supernatants from day 1 to day 3 post-infection. It is also noteworthy that the patterns of results were different when cell 
cultures were treated with FLX before, during, or after the inoculation of SARS-CoV-2. The administration of FLX prior to the infection was more effective in delaying the onset of $\mathrm{CPE}$ and infectious particles in culture supernatants up to 3 days post-infection. A daily treatment of cultures with $10 \mu \mathrm{M}$ of FLX also extended the delay. The effect of FLX observed in our experiments is reminiscent of the results of other studies reporting that $4.6 \mu \mathrm{M}$ of FLX added to Vero cell cultures prior to the infection with SARS-CoV-2 at MOI 0.5 resulted in a reduction of the level of viral RNA in culture supernatants [20]. Our results regarding the effect of $10 \mu \mathrm{M}$ of FLX added to cell cultures after the inoculation of SARS-CoV-2 are in agreement with those of Schloer et al. showing around a $2 \log$ reduction of the viral titer in supernatants $48 \mathrm{~h}$ post inoculation [21].

The FLX mechanisms involved in the inhibition of SARS-CoV-2 have been recently investigated. As far as enveloped viruses are concerned, they can enter cells through endocytic pathway and in this case the endosomal environment, including $\mathrm{pH}$, proteases, ions, intracellular receptors, and lipid composition, is important to the virus-endosome fusion $[30,31]$. SARS-CoV-2 enters into host cell by the binding of its viral surface spike (S) protein to the angiotensin-converting enzyme 2 (ACE2) on the surface of the cell and the priming of the spike (S) protein by the transmembrane protease serine 2 (TMPRSS2), leading to virus particles endocytosis and fusion of the viral and cellular membranes [27] (Figure 4). Schloer et al. found that the treatment of Vero E6 cells with FLX can inhibit SARSCoV-2 entry into cells through endocytic pathway by inducing accumulation of cholesterol within the endosomes [21] leading to inactivation of the endolysosomal proton pump responsible for $\mathrm{pH}$ maintenance and therefore resulting in impairment of endolysosomal acidification [32,33] (Figure 4).

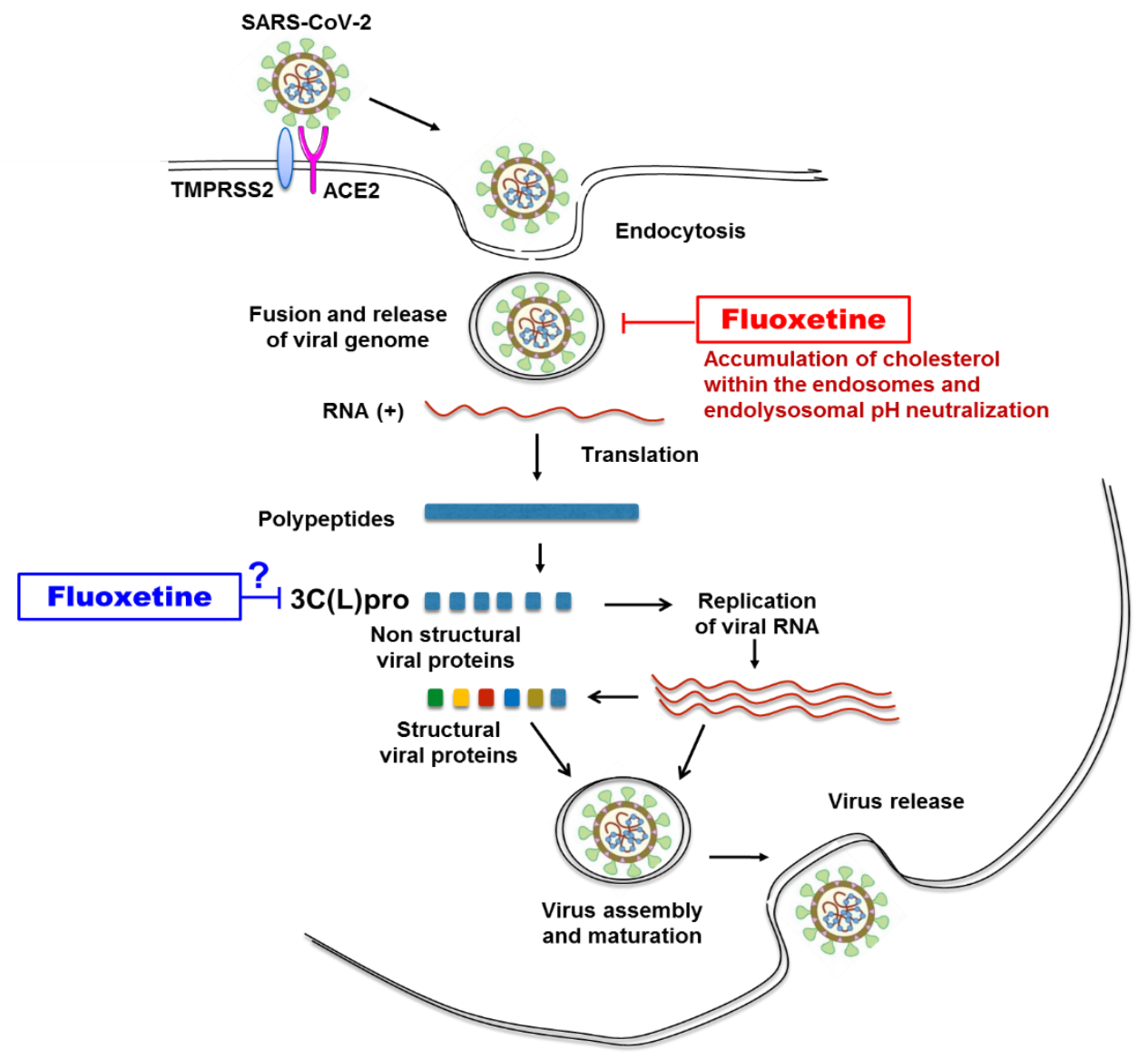

Figure 4. Antiviral activity of fluoxetine: known or potential targets of fluoxetine in steps of SARS-CoV-2 replication in permissive cell. 
FLX proved to be efficient in inhibiting several types of viruses through various other mechanisms. Regarding dengue virus, FLX most probably has an impact at the initiation of viral RNA replication [18], whereas in the case of CVBs, the putative target of FLX was the viral 2C protein whose function remains partially unknown $[23,34]$.

Interestingly, similar to SARS-CoV-2, which contains a 3C-like protease, a target of SARS-CoV-2 drugs [35], coxsackieviruses contain a virally encoded chymotrypsin-like protease named 3C pro responsible for viral replication [36]. 3C-like proteases (3C(L)pro) are widely found in (+)ssRNA viruses. All of them are cysteine proteases with a chymotrypsinlike fold (PA clan), using a catalytic dyad or triad. They share some general similarities on substrate specificity and inhibitor effectiveness [37]. Whether FLX inhibits the replication of SARS-CoV-2 and CV-B4 through an effect on this protein deserves further study (Figure 4). FLX can inhibit SARS-CoV-2 and CV-B4 in Vero E6 cultures. The antiviral activity of FLX in these models opens a new avenue to study the interactions between these viruses and the cell and possibly to find new angles of attack. Elucidating the mechanism of the antiviral effect of FLX may pave way for novel combating strategies, especially for SARS-CoV-2.

FLX can also act on cytokine production and prevent cytokine storm in animal models of septic shock and allergic asthma through its anti-inflammatory activity [38,39]. Furthermore, in vivo experiments assessed FLX effects on inflammation in early brain injury, possibly involving the TLR4/MyD88/NF-кB signaling pathway [40]. Moreover, during SARS-CoV-2 infection, inflammation may have deleterious effects on the function of lungs and other organs and therefore on the survival of patients. Interestingly, it has been reported that the non-serotonergic anti-inflammatory effect of FLX potentially has the ability to inhibit IL-6 and NF-kB signaling pathways driving the cytokine storm in COVID-19 [41]. Taken altogether, these observations suggest that FLX could be relevant in vivo to control SARS-CoV-2 infection and to treat COVID-19. Recently the results of an in silico study suggested that the standard $20 \mathrm{mg}, 40 \mathrm{mg}$, and $60 \mathrm{mg}$ daily doses of FLX used in routine psychiatric treatments [42] achieve the non-toxic levels of FLX in lungs higher than $10 \mu \mathrm{M}$ [43] which is a concentration effective to inhibit the infection with SARS-CoV-2 in vitro in our experiments and in those of others [21]. Thus, a COVID-19 therapy based on FLX might constitute a relevant approach to fight against SARS-CoV-2 infection and reduce COVID-19 severity. The results of in vitro or in silico studies are not an absolute guarantee of the effect in infected individuals; however, these encouraging observations deserve some attention and should prompt further studies to determine whether FLX has an effect on SARS-CoV-2 in primary cells and eventually in vivo.

In conclusion, FLX can inhibit SARS-CoV-2 in vitro. Interestingly, it was recently reported that 35 patients under treatment with a standard fluoxetine dose of $20 \mathrm{mg}$ had a lower risk of intubation and death when they were hospitalized for COVID-19 [44]. It would be useful to assess the outcome of SARS-CoV-2 infection in a larger cohort of people receiving FLX, as it is a well-known treatment of depression worldwide. Further studies are needed to elucidate the mechanism of the antiviral effect of this molecule and investigate its potential in combating SARS-CoV-2 infections. Future studies will be directed along this line in our laboratory.

Author Contributions: Methodology: A.D., F.S., S.B., J.D., I.E., E.K.A.; writing-original draft preparation: A.D., M.P.N.; supervision: J.D., D.H.; conceptualization, writing-review and editing: D.H. All authors have read and agreed to the published version of the manuscript.

Funding: This research received no external funding.

Institutional Review Board Statement: Not applicable.

Informed Consent Statement: Not applicable.

Data Availability Statement: Not applicable.

Acknowledgments: We thank Jennifer Varghese for English language editing.

Conflicts of Interest: The authors declare no conflict of interest. 


\section{References}

1. He, Y.; Wang, J.; Li, F.; Shi, Y. Main clinical features of COVID-19 and potential prognostic and therapeutic value of the microbiota in Sars-Cov-2 infections. Front. Microbiol. 2020, 11, 1302. [CrossRef]

2. Sharma, V.K.; Jinadatha, C.; Lichtfouse, E. Environmental chemistry is most relevant to study coronavirus pandemics. Environ. Chem. Lett. 2020, 18, 993-996. [CrossRef]

3. Glencross, D.A.; Ho, T.-R.; Camiña, N.; Hawrylowicz, C.M.; Pfeffer, P.E. Air pollution and its effects on the immune system. Free. Radic. Biol. Med. 2020, 151, 56-68. [CrossRef] [PubMed]

4. Jiang, Y.; Wu, X.-J.; Guan, Y.-J. Effect of ambient air pollutants and meteorological variables on COVID-19 incidence. Infect. Control. Hosp. Epidemiol. 2020, 41, 1011-1015. [CrossRef] [PubMed]

5. Bashir, M.F.; Ma, B.J.; Bilal; Komal, B.; Farooq, T.H.; Iqbal, N.; Bashir, M. Correlation between environmental pollution indicators and COVID-19 pandemic: A brief study in Californian context. Environ. Res. 2020, 187, 109652. [CrossRef] [PubMed]

6. Zhu, Y.; Xie, J.; Huang, F.; Cao, L. Association between short-term exposure to air pollution and COVID-19 infection: Evidence from China. Sci. Total Environ. 2020, 727, 138704. [CrossRef] [PubMed]

7. Roviello, V.; Roviello, G.N. Lower COVID-19 mortality in Italian forested areas suggests immunoprotection by Mediterranean plants. Environ. Chem. Lett. 2020, 1-12. [CrossRef]

8. Ramajayam, R.; Tan, K.-P.; Liang, P.-H. Recent development of 3C and 3CL protease inhibitors for anti-coronavirus and antipicornavirus drug discovery. Biochem. Soc. Trans. 2011, 39, 1371-1375. [CrossRef]

9. De Wit, E.; Van Doremalen, N.; Falzarano, D.; Munster, V.J. SARS and MERS: Recent insights into emerging coronaviruses. Nat. Rev. Microbiol. 2016, 14, 523-534. [CrossRef]

10. Prajapat, M.; Sarma, P.; Shekhar, N.; Avti, P.; Sinha, S.; Kaur, H.; Kumar, S.; Bhattacharyya, A.; Kumar, H.; Bansal, S.; et al. Drug targets for corona virus: A systematic review. Indian J. Pharmacol. 2020, 52, 56-65.

11. Mehta, N.; Mazer-Amirshahi, M.; Alkindi, N.; Pourmand, A. Pharmacotherapy in COVID-19; A narrative review for emergency providers. Am. J. Emerg. Med. 2020, 38, 1488-1493. [CrossRef] [PubMed]

12. Ali, M.J.; Hanif, M.; Haider, M.A.; Ahmed, M.U.; Sundas, F.; Hirani, A.; Khan, I.A.; Anis, K.; Karim, A.H. Treatment options for COVID-19: A review. Front. Med. 2020, 7, 480. [CrossRef]

13. Tu, Y.F.; Chien, C.S.; Yarmishyn, A.A.; Lin, Y.Y.; Luo, Y.H.; Lin, Y.T.; Lai, W.Y.; Yang, D.M.; Chou, S.J.; Yang, Y.P.; et al. A review of sars-cov-2 and the ongoing clinical trials. Int. J. Mol. Sci. 2020, 21, 2657. [CrossRef]

14. Siemieniuk, R.A.; Bartoszko, J.J.; Ge, L.; Zeraatkar, D.; Izcovich, A.; Kum, E.; Pardo-Hernandez, H.; Rochwerg, B.; Lamontagne, F.; Han, M.A.; et al. Drug treatments for covid-19: Living systematic review and network meta-analysis. BMJ 2020, 370, m2980. [CrossRef] [PubMed]

15. McKee, D.L.; Sternberg, A.; Stange, U.; Laufer, S.; Naujokat, C. Candidate drugs against SARS-CoV-2 and COVID-19. Pharmacol Res. 2020, 157, 104859. [CrossRef]

16. Racaniello, V.R. Picornaviridae: The viruses and their replication. In Fields Virology; Lippincott Williams \& Wilkins: Philadelphia, PA, USA, 2013; pp. 453-490.

17. Bauer, L.; Lyoo, H.; Van Der Schaar, H.M.; Strating, J.R.; Van Kuppeveld, F.J. Direct-acting antivirals and host-targeting strategies to combat enterovirus infections. Curr. Opin. Virol. 2017, 24, 1-8. [CrossRef]

18. Medigeshi, G.R.; Kumar, R.; Dhamija, E.; Agrawal, T.; Kar, M. N-desmethylclozapine, fluoxetine, and salmeterol inhibit postentry stages of the dengue virus life cycle. Antimicrob. Agents Chemother. 2016, 60, 6709-6718. [CrossRef]

19. Young, K.-C.; Bai, C.-H.; Su, H.-C.; Tsai, P.-J.; Pu, C.-Y.; Liao, C.-S.; Lin, Y.-M.; Lai, H.-W.; Chong, L.-W.; Tsai, Y.-S.; et al. Fluoxetine a novel anti-hepatitis $C$ virus agent via ROS-, JNK-, and PPAR $\beta / \gamma$-dependent pathways. Antivir. Res. 2014, 110, $158-167$. [CrossRef] [PubMed]

20. Zimniak, M.; Kirschner, L.; Hilpert, H.; Seibel, J.; Bodem, J. The serotonin reuptake inhibitor fluoxetine inhibits SARS-CoV-2. BioRxiv 2020. [CrossRef]

21. Schloer, S.; Brunotte, L.; Goretzko, J.; Mecate-Zambrano, A.; Korthals, N.; Gerke, V.; Ludwig, S.; Rescher, U. Targeting the endolysosomal host-SARS-CoV-2 interface by clinically licensed functional inhibitors of acid sphingomyelinase (FIASMA) including the antidepressant fluoxetine. Emerg. Microbes Infect. 2020, 9, 2245-2255. [CrossRef] [PubMed]

22. Bauer, L.; Manganaro, R.; Coutard, B.; Brancale, A.; Van Kuppeveld, F.J.; Zonsics, B.; Strating, J.R.P.M.; El Kazzi, P.; Lopez, M.L.; Ulferts, R.; et al. Fluoxetine inhibits enterovirus replication by targeting the viral $2 \mathrm{C}$ protein in a stereospecific manner. ACS Infect. Dis. 2019, 5, 1609-1623. [CrossRef]

23. Ulferts, R.; Van Der Linden, L.; Thibaut, H.J.; Lanke, K.H.W.; Leyssen, P.; Coutard, B.; De Palma, A.M.; Canard, B.; Neyts, J.; Van Kuppeveld, F.J. Selective serotonin reuptake inhibitor fluoxetine inhibits replication of human enteroviruses B and D by targeting viral protein 2C. Antimicrob. Agents Chemother. 2013, 57, 1952-1956. [CrossRef] [PubMed]

24. Zuo, J.; Quinn, K.K.; Kye, S.; Cooper, P.; Damoiseaux, R.; Krogstad, P. Fluoxetine is a potent inhibitor of coxsackievirus replication. Antimicrob. Agents Chemother. 2012, 56, 4838-4844. [CrossRef]

25. Alidjinou, E.K.; Sane, F.; Bertin, A.; Caloone, D.; Hober, D. Persistent infection of human pancreatic cells with Coxsackievirus B4 is cured by fluoxetine. Antivir. Res. 2015, 116, 51-54. [CrossRef] [PubMed]

26. Benkahla, M.A.; Alidjinou, E.K.; Sane, F.; Desailloud, R.; Hober, D. Fluoxetine can inhibit coxsackievirus-B4 E2 in vitro and in vivo. Antivir. Res. 2018, 159, 130-133. [CrossRef] 
27. Hoffmann, M.; Kleine-Weber, H.; Müller, M.A.; Drosten, C.; Pöhlmann, S.; Schroeder, S.; Krüger, N.; Herrler, T.; Erichsen, S.; Schiergens, T.S.; et al. SARS-CoV-2 cell entry depends on ACE2 and TMPRSS2 and is blocked by a clinically proven rrotease inhibitor. Cell 2020, 181, 271-280.e8. [CrossRef]

28. Institut Pasteur, Paris. Protocol: Real-Time RT-PCR Assays for the Detection of SARS CoV-2. Available online: https: //www.who.int/docs/default-source/coronaviruse/real-time-rt-pcr-assays-for-the-detection-of-sars-cov-2-institut-pasteurparis.pdf?sfvrsn=3662fcb6_2 (accessed on 29 January 2021).

29. Sawyer, E.; Howell, L.L. Pharmacokinetics of fluoxetine in rhesus macaques following multiple routes of administration. Pharmacology 2011, 88, 44-49. [CrossRef] [PubMed]

30. White, J.M.; Whittaker, G.R. Fusion of enveloped viruses in endosomes. Traffic 2016, 17, 593-614. [CrossRef]

31. Staring, J.; Raaben, M.; Brummelkamp, T.R. Viral escape from endosomes and host detection at a glance. J. Cell Sci. 2018, 131, jcs216259. [CrossRef]

32. Lafourcade, C.; Sobo, K.; Kieffer-Jaquinod, S.; Garin, J.; Van Der Goot, F.G. Regulation of the V-ATpase along the endocytic pathway occurs through reversible subunit association and membrane localization. PLoS ONE 2008, 3, e2758. [CrossRef]

33. Marshansky, V.; Futai, M. The V-type H+-ATPase in vesicular trafficking: Targeting, regulation and function. Curr. Opin. Cell Biol. 2008, 20, 415-426. [CrossRef] [PubMed]

34. Alidjinou, E.K.; Bertin, A.; Sane, F.; Lobert, D.; Engelmann, I.; Hober, D. Emergence of fluoxetine-resistant variants during treatment of human pancreatic cell cultures persistently infected with coxsackievirus B4. Viruses 2019, 11, 486. [CrossRef] [PubMed]

35. He, J.; Hu, L.; Huang, X.; Wang, C.; Zhang, Z.; Wang, Y.; Zhang, D.; Ye, W. Potential of coronavirus 3C-like protease inhibitors for the development of new anti-SARS-CoV-2 drugs: Insights from structures of protease and inhibitors. Int. J. Antimicrob. Agents 2020, 56, 106055. [CrossRef]

36. Porter, A.G. Picornavirus nonstructural proteins: Emerging roles in virus replication and inhibition of host cell functions. J. Virol. 1993, 67, 6917-6921. [CrossRef] [PubMed]

37. Kim, Y.; Lovell, S.; Tiew, K.-C.; Mandadapu, S.R.; Alliston, K.R.; Battaile, K.P.; Groutas, W.C.; Chang, K.-O. Broad-spectrum antivirals against $3 C$ or $3 C$-like proteases of picornaviruses, noroviruses, and coronaviruses. J. Virol. 2012, 86, 11754-11762. [CrossRef] [PubMed]

38. Roumestan, C.; Michel, A.; Bichon, F.; Portet, K.; Detoc, M.; Henriquet, C.; Jaffuel, D.; Mathieu, M. Anti-inflammatory properties of desipramine and fluoxetine. Respir. Res. 2007, 8, 35. [CrossRef]

39. Sherkawy, M.M.; Abo-Youssef, A.M.; Salama, A.A.A.; Ismaiel, I.E. Fluoxetine protects against OVA induced bronchial asthma and depression in rats. Eur. J. Pharmacol. 2018, 837, 25-32. [CrossRef]

40. Liu, F.-Y.; Cai, J.; Wang, C.; Ruan, W.; Guan, G.-P.; Pan, H.-Z.; Li, J.-R.; Qian, C.; Chen, J.-S.; Wang, L.; et al. Fluoxetine attenuates neuroinflammation in early brain injury after subarachnoid hemorrhage: A possible role for the regulation of TLR4/MyD88/NFкB signaling pathway. J. Neuroinflam. 2018, 15, 1-14. [CrossRef]

41. Creeden, J.; Imami, A.S.; Eby, H.M.; Gillman, C.; Becker, K.N.; Reigle, J.; Andari, E.; Pan, Z.K.; O’Donovan, S.M.; McCullumsmith, R.E.; et al. Fluoxetine as an Anti-Inflammatory Therapy in SARS-CoV-2 Infection. SSRN Electron. J. 2020. [CrossRef]

42. Wood, A.J.J.; Gram, L.F. Fluoxetine. N. Engl. J. Med. 1994, 331, 1354-1361. [CrossRef] [PubMed]

43. Eugene, A.R. Fluoxetine pharmacokinetics and tissue distribution suggest a possible role in reducing SARS-CoV-2 titers. MedRxiv 2020. [CrossRef]

44. Hoertel, N.; Sánchez, M.; Vernet, R.; Beeker, N.; Jannot, A.S.; Neuraz, A.; Salamanca, E.; Paris, N.; Daniel, C.; Gramfort, A.; et al. Association between SSRI antidepressant use and reduced risk of intubation or death in hospitalized patients with coronavirus disease 2019: A multicenter retrospective observational study. MedRxiv 2020. [CrossRef] 